\title{
Riannodare il passato e il presente con la restituzione prospettica: ricostruzione della perduta chiesa delle Stimmate di Palermo da foto d'archivio
}

\author{
Fabrizio Agnello \\ Laura Barrale
}

Abstract

La restituzione prospettica appartiene di diritto al corpus disciplinare della geometria descrittiva, come problema inverso della prospettiva. In passato tale tecnica è stata utilizzata ben poche volte per la ricostruzione da immagini fotografiche di architetture e opere d'arte perdute; gli strumenti digitali per la rappresentazione offrono però l'opportunità di recuperare la restituzione prospettica come strumento efficace per la ricostruzione di monumenti perduti ritratti in foto d'epoca.

II caso studio prescelto è la chiesa delle Stimmate di Palermo, demolita alla fine del XIX secolo per la costruzione del Teatro Massimo. La chiesa ad aula era delimitata da pareti con nicchie arcuate poco profonde, decorate da pregiati stucchi che vengono preservati dalla demolizione e sono oggi custoditi presso l'Oratorio dei Bianchi di Palermo.

Nessun disegno documenta la consistenza della chiesa demolita; uniche tracce documentarie sopravvissute sono tre fotografie di mediocre qualità, che ritraggono le due nicchie contrapposte della chiesa, decorate dagli stucchi. La tecnica della restituzione prospettica ha consentito la ricostruzione proporzionale delle due nicchie; il rilievo con laser scanner degli stucchi esposti all'Oratorio dei Bianchi ha supportato la scalatura e l'orientamento del modello prospettico e, infine, la ricollocazione virtuale di tutti gli elementi scultorei sopravvissuti nel modello ricostruttivo della chiesa.

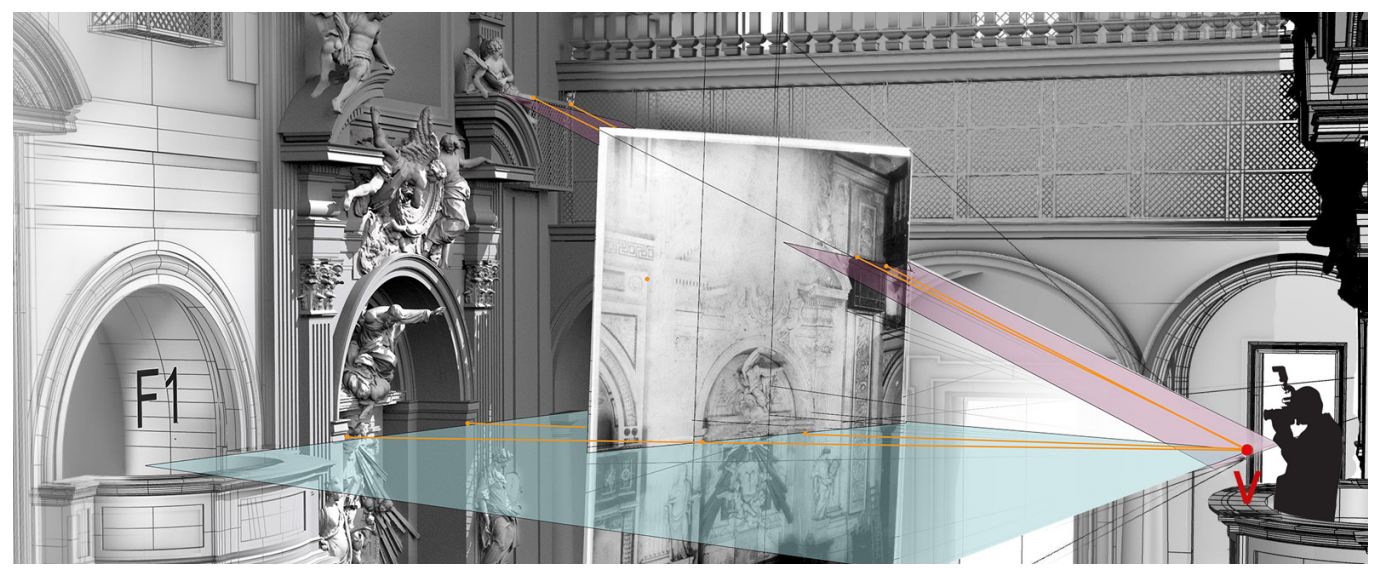




\section{Introduzione}

La restituzione prospettica, nella sua declinazione digitale, consente di ricostruire, nello spazio tridimensionale, luoghi e monumenti scomparsi, la cui memoria è affidata a poche fotografie. A questa fattispecie è riconducibile la chiesa delle Stimmate, costruita nei primi anni del XVII secolo sul margine settentrionale della città murata di Palermo. La chiesa e l'annesso monastero femminile vengono demoliti nel 1890 nell'ambito di un vasto programma di trasformazione urbana finalizzato alla demolizione di un tratto consistente della cinta muraria cinquecentesca e alla costruzione del Teatro Massimo, principale teatro lirico di Palermo. Come gran parte delle chiese annesse ai monasteri femminili, la chiesa delle Stimmate aveva un'unica navata, delimitata da pareti con nicchie poco profonde e conclusa da un'abside rettangolare; due nicchie contrapposte, poste in prossimità dell'ingresso, erano decorate da sculture in stucco, realizzate da Giacomo Serpotta, uno dei più importanti artisti siciliani del periodo.

Gli stucchi vennero asportati poco prima della demolizione della chiesa ed esposti nel Museo Nazionale di Palermo (oggi Museo archeologico Salinas); alla fine del millennio vengono restaurati e allestiti al piano terra dell'Oratorio dei Bianchi, sede aggiunta della Galleria Regionale di Palazzo Abatellis (fig. I).

Nessuna documentazione grafica della chiesa è giunta a noi; in un dipinto di autore ignoto degli inizi del XVIII secolo, che raffigura in modo paratattico i monumenti di Palermo siti lungo il percorso della processione religiosa di Santa Rosalia [I], compare la raffigurazione della facciata di una chiesa con la dicitura Badia Delli Stimmati. La facciata dipinta ha tuttavia poca rilevanza sotto il profilo documentario poiché ha l'assetto tipico del fronte di una chiesa a tre navate.

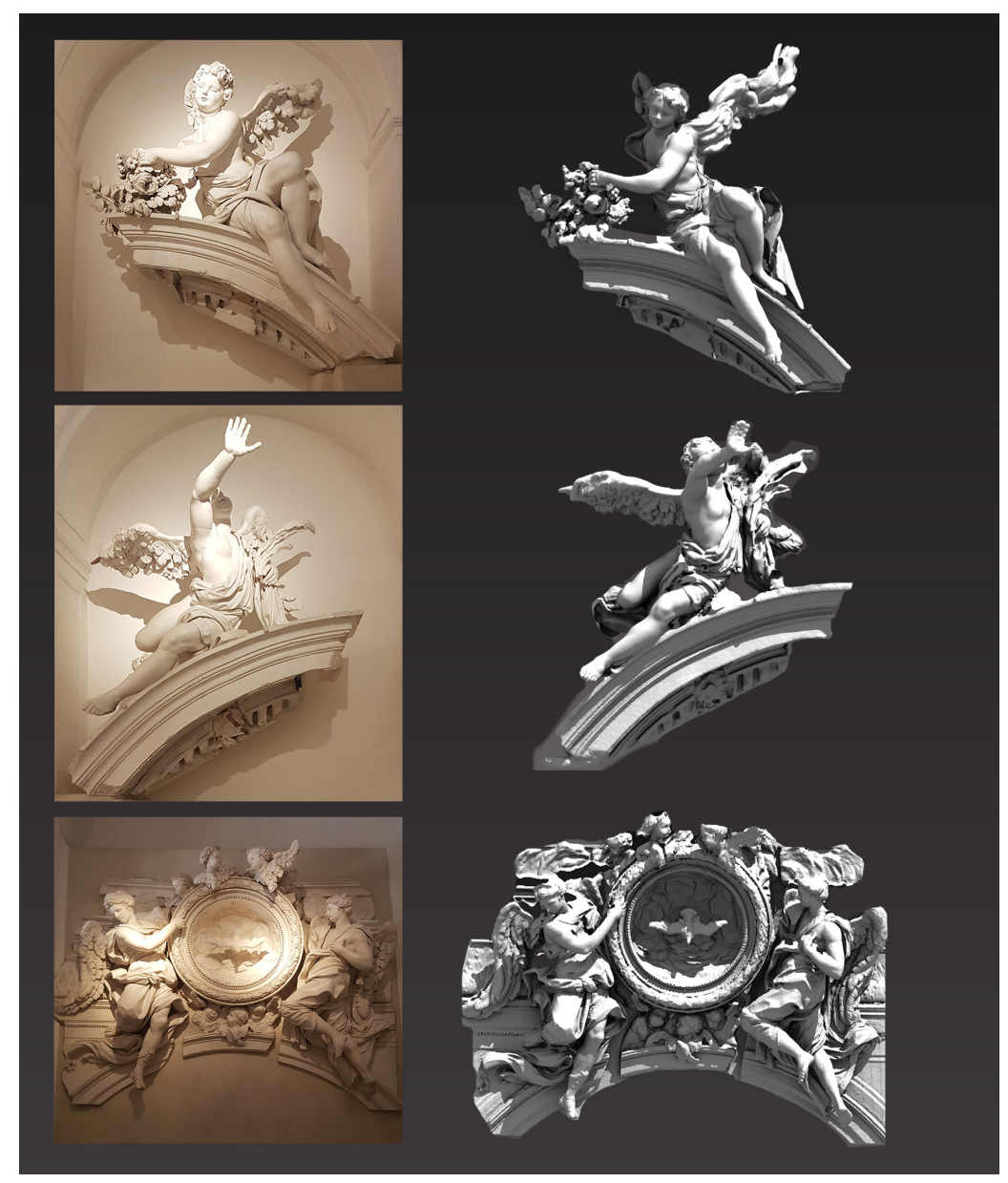


Altro documento, ben più affidabile, è il Piano di Massima della ubicazione del nuovo Teatro, redatto da Giovan Battista Filippo Basile, architetto incaricato per il progetto e la costruzione del Teatro Massimo. II Piano di Basile è un'accurata planimetria dello stato di fatto dei luoghi, cui viene sovrapposta la linea perimetrale del nuovo teatro. II confronto con la cartografia del centro storico di Palermo del 198 I e con il rilievo con laser scanner dell'area, ha confermato l'accuratezza metrica del Piano.

II perimetro della chiesa delle Stimmate, chiaramente delineato nel Piano, ha permesso di risalire alle sue dimensioni planimetriche complessive.

Le uniche fonti documentarie relative all'assetto spaziale degli spazi interni della chiesa sono tre fotografie, risalenti al mese di luglio del 1890, poco prima della demolizione; le foto, che ritraggono esclusivamente le nicchie con gli stucchi (fig. 2), sono state probabilmente scattate per documentarne la posizione originaria in vista di una successiva esposizione in una struttura museale. Le tre immagini, di mediocre qualità, sono pervenute a noi attraverso pubblicazioni che non riportano indicazioni sulla provenienza delle foto. Gli stucchi, realizzati da Giacomo Serpotta, artista di primo piano nel contesto culturale di Palermo nel XVII secolo, costituivano l'elemento di maggior pregio della Chiesa.
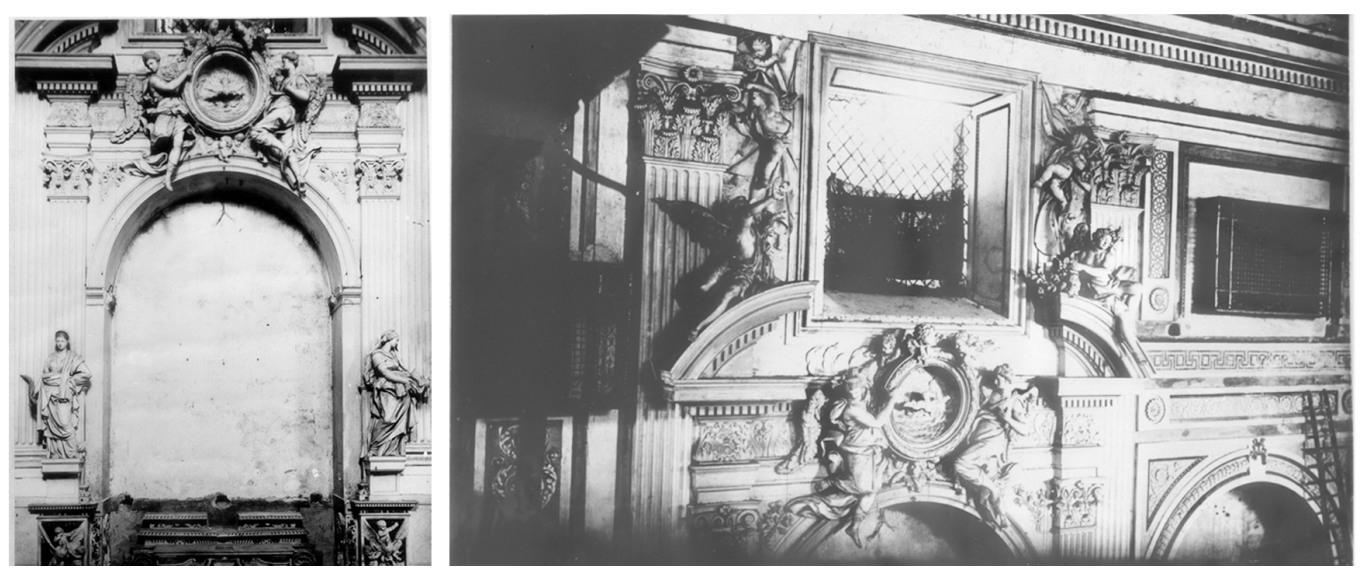

\section{Stato dell'arte}

La restituzione prospettica appartiene di diritto al corpus disciplinare della geometria descrittiva, come problema inverso della prospettiva. In passato tale tecnica è stata utilizzata ben poche volte per la ricostruzione da foto d'epoca di architetture e opere d'arte perdute, probabilmente a causa dei margini di approssimazione tipici degli strumenti tradizionali del disegno, inadeguati a garantire sufficiente accuratezza alla restituzione da immagini fotografiche. Le ridotte dimensioni della riproduzione a stampa della foto, la posizione spesso inaccessibile dei punti di fuga, la restituzione limitata al ribaltamento di figure piane sul quadro dell'immagine, hanno confinato la restituzione prospettica a una condizione di marginalità nel vasto ambito delle produzioni finalizzate alla ricostruzione congetturale.

La disponibilità di 'nuovi' strumenti digitali per il disegno offre oggi l'opportunità di valorizzare questa 'vecchia' tecnica, aumentando la sua accuratezza ed efficacia. Poche pubblicazioni, per le quali si rimanda alla bibliografia, documentano un iniziale ma solido interesse degli studiosi di scienza della rappresentazione verso la declinazione digitale della restituzione prospettica e la sua applicazione a immagini fotografiche.

La tecnologia digitale ha migliorato sensibilmente approccio ed esiti della restituzione prospettica; la dimensione illimitata del piano di lavoro rende possibile l'individuazione di punti di fuga anche molto distanti dall'immagine; la restituzione può 'staccarsi' dal piano dell'immagine e operare direttamente nello spazio tridimensionale; la possibilità di impostare 'camere' 
coincidenti con il centro di proiezione, consente di operare direttamente sul modello tridimensionale controllando in tempo reale la corrispondenza fra dimensione e posizione di un elemento e la sua immagine fotografica.

Il processo di restituzione prospettica può dunque utilmente applicarsi alla costruzione di modelli tridimensionali.

È tuttavia ben noto che la restituzione prospettica, come tutte le tecniche fotogrammetriche, non sia in grado di restituire direttamente misure, ma solo proporzioni; affinché le entità geometriche restituite in corretta proporzione possano diventare misurabili, occorre scalare il modello fotogrammetrico attraverso la conoscenza della dimensione di enti geometrici raffigurati in una o più immagini fotografiche.

II rilievo fotogrammetrico, e con esso la restituzione prospettica, diventa 'metrico' solo grazie a misurazioni eseguite con procedure diverse, dirette, topografiche o laser scanning.

Nei casi in cui il rilievo di un elemento raffigurato nell'immagine venga eseguito con tecniche laser scanning, si giunge alla produzione di una nuvola di punti (o di una mesh) che ne documenta la consistenza tridimensionale; in questo caso la 'scalatura' del modello fotogrammetrico può utilizzare una delle dimensioni dell'elemento, ma soprattutto può essere eseguita una verifica visiva della accuratezza dello schema di restituzione prospettica attraverso la corrispondenza, dal centro di proiezione, fra il modello dell'elemento e la sua immagine fotografica.

\section{Orientamento delle foto}

Il primo passaggio del processo di restituzione consiste, ovviamente, nell'inserimento dell'immagine digitalizzata in un software di rappresentazione digitale [2]. Non è assolutamente importante assegnare all'immagine una dimensione definita, poiché l'intero schema prospettico può essere scalato rigidamente in qualsiasi momento.

In condizioni ideali (una foto digitale, ad esempio) il punto principale, ossia il punto di fuga delle rette ortogonali al quadro, coincide con l'intersezione delle diagonali del rettangolo che delimita l'immagine.

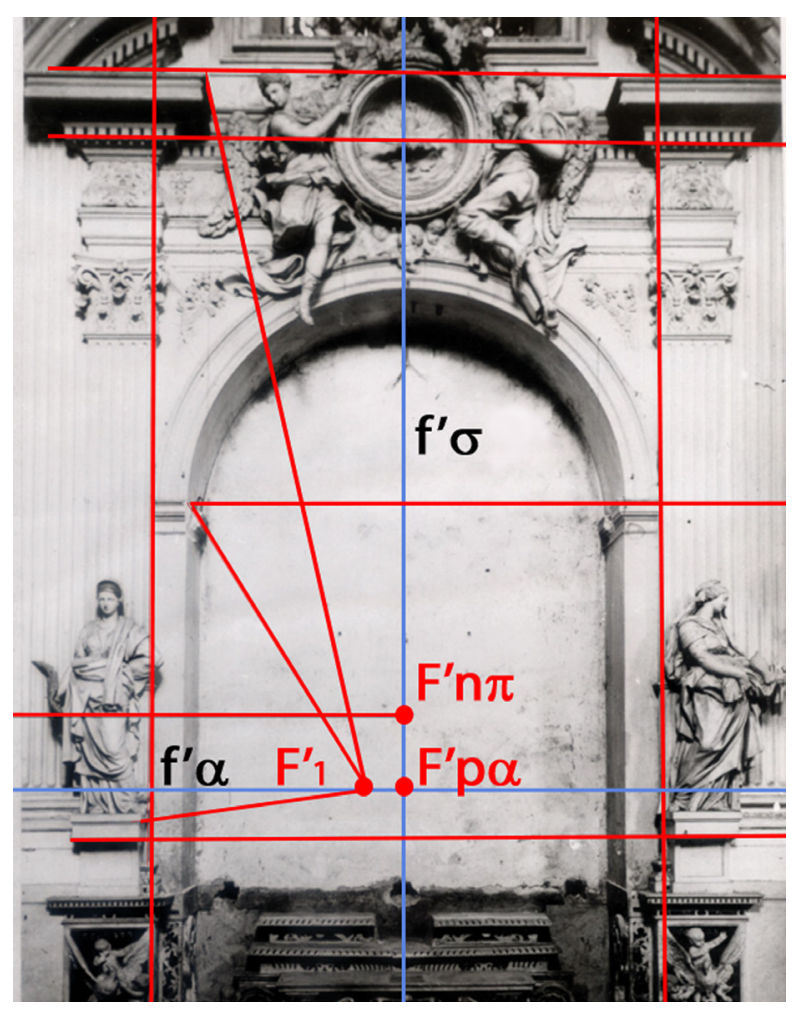


Quando si opera su immagini che vengono acquisite da pubblicazioni o da altre fonti, può accadere che il punto principale si trovi in posizione diversa; ciò accade di solito quando:

- l'immagine originaria è stata ritagliata per esigenze editoriali;

- l'immagine è stata acquisita con una macchina fotografica dotata di banco ottico, un dispositivo utilizzato per mitigare la convergenza delle rette verticali (fig. 3).

Nel primo caso può essere utile la conoscenza delle proporzioni del negativo o della lastra di vetro utilizzata, ovvero una ricerca sulla datazione dell'immagine e sui formati di maggiore diffusione del periodo.

II secondo passaggio è stato dedicato alla individuazione di F'n $\alpha$, punto di fuga delle rette verticali [3]; lavorando con le immagini fotografiche è pressoché impossibile trovare rette verticali parallele tra loro, condizione che si verificherebbe qualora il quadro fosse verticale, ossia qualora il fotografo avesse eseguito lo scatto tenendo l'asse di presa in posizione perfettamente orizzontale. Una delle ragioni che ha reso difficile la restituzione da fotografie con gli strumenti tradizionali del disegno, è proprio la distanza di F'n $\alpha$ dall'immagine, dovuta alla limitata inclinazione della camera al momento della foto (fig. 4).

Il terzo passaggio mira all'identificazione della Linea d'orizzonte, $f \alpha$, attraverso l'uso di due punti di fuga di rette orizzontali; la f $\alpha$ non risulta quasi mai parallela ai margini orizzontali dell'immagine fotografica; tale condizione presupporrebbe che il fotografo, al momento dello scatto, avesse tenuto la base della macchina fotografica perfettamente orizzontale. Eseguita la rotazione utile a conferire direzione orizzontale alla $f \alpha$, si prowede a disegnare la retta di fuga del piano sezione retta del diedro formato da $\alpha$ e $\pi$; la fo passa per F'n $\alpha$ [4], è ortogonale alla $f^{\prime} \alpha$ e la interseca in $F^{\prime} p \alpha$, punto di fuga delle rette di massima pendenza dei piani orizzontali nel diedro che essi formano con il quadro (il piano dell'immagine) (fig. 5). La conoscenza dell'angolo formato dalle rette orizzontali utilizzate per il ritrovamento dei punti di fuga, consente il tracciamento di una circonferenza che passa per tali punti [5]. L'intersezione tra la fo e tale arco di circonferenza, è $(V) \underline{\alpha}$, ribaltamento sul quadro del centro di proiezione $V$, secondo il piano proiettante orizzontale (cerniera del ribaltamento $f \alpha$ ).

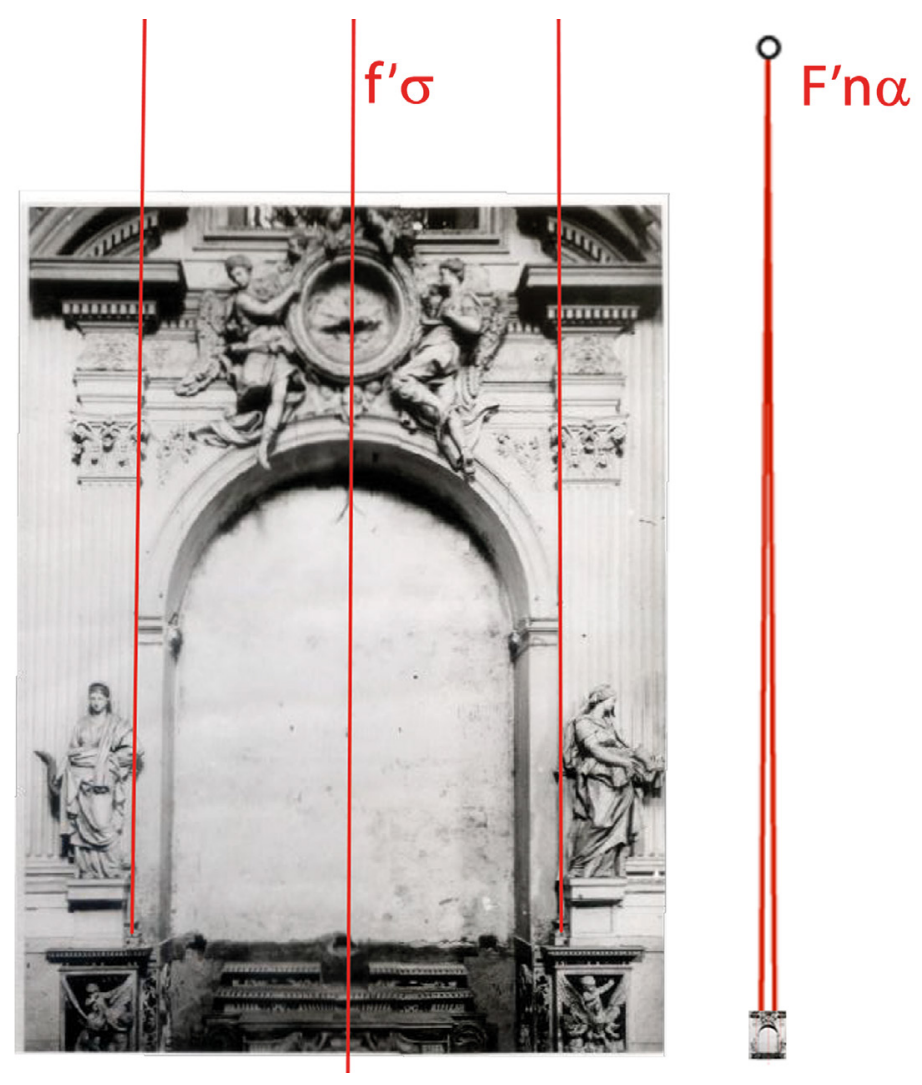


II segmento che ha per estremi $F^{\prime} p \alpha$ e $(V) \underline{\alpha}$ è il ribaltamento su $\pi$ del segmento della retta di massima pendenza del piano orizzontale che ha estremi F'p $\alpha$ e V; riportando tale distanza, con centro in $F^{\prime} p \alpha$, sulla semicirconferenza che ha come diametro il segmento da $F^{\prime} p \alpha$ a F'n $\alpha$ [6] della $f^{\prime} \sigma$, si trova $(V) \underline{\sigma}$, ribaltamento del centro di proiezione $V$ secondo il piano sezione retta proiettante (cerniera $f \sigma$ ), e con esso la distanza principale $\Delta$ e il punto principale $F^{\prime} n \pi$ (fig. 6).

Attraverso le seguenti rotazioni è stato ricostruito l'assetto tridimensionale dello schema prospettico:

- una rotazione di $90^{\circ}$ intorno alla $f \sigma$ ha restituito la posizione di $V$ nello spazio;

- una rotazione sul piano $\sigma$ ha assegnato direzione verticale alla retta che unisce V e F'n $\alpha$ e, conseguentemente, giacitura orizzontale al piano $\alpha$ (fig. 7);

- una rotazione sul piano $\alpha$ ha assegnato a una direzione orizzontale dello schema prospettico la direzione corrispondente dell'elemento 3D scelto per la scalatura del modello prospettico.

La regola del parallelogramma è stata applicata (fig. 8):

- utilizzando il segmento $A^{\prime} B^{\prime}$ della retta $r$ che fuga in $F^{\prime}$;

- individuando il corrispondente segmento $A B$ sulla retta $r$ dell'elemento 3D;

- tracciando le rette proiettanti per A' e $B^{\prime}$;

- riportando sul segmento da $V$ a $F^{\prime}$, un segmento $V K$, di lunghezza pari ad $A B$;

- tracciando dal punto K la parallela alla retta proiettante che passa per A' e determinando, per intersezione, il punto $B$;

- traslando l'elemento 3D fino a far coincidere il punto $B$ ricostruito con il punto $B$ dell'elemento.

La verifica della qualità della ricostruzione dello schema prospettico viene condotta impostando una camera sul centro di proiezione e con lunghezza focale corrispondente alla distanza principale $\Delta$; assegnando un fattore di trasparenza alla fotografia, è possibile verificare la corrispondenza fra l'elemento 3D e la sua immagine.

La definizione dello schema prospettico è dunque completata e la fase di restituzione può essere avviata.

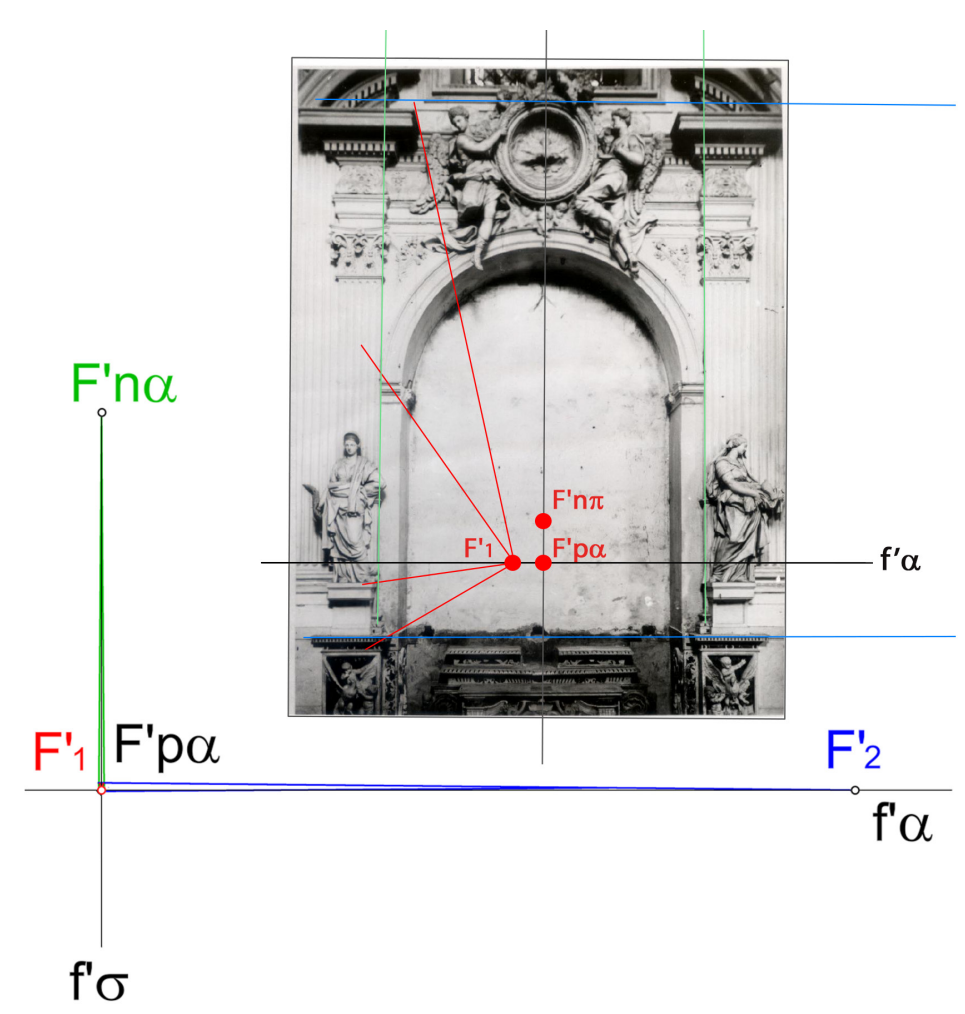


Dopo aver associato un piano verticale alla parete di fondo degli stucchi, le rette che strutturano la forma delle nicchie state determinate con l'ausilio di piani proiettanti, individuati da tre punti: il centro di proiezione $V$, il punto di fuga della retta che si vuole restituire, un punto della retta sull'immagine; l'intersezione tra il piano proiettante e la fotografia deve sovrapporsi esattamente all'immagine della retta (fig. 9).

La restituzione prospettica può essere condotta con una procedura a catena, utilizzando per la scalatura e l'orientamento di alcune foto, dimensioni e direzioni ricavate da altre fotografie; nel caso qui presentato, la fotografia della parte alta della nicchia, che include la parte sommitale della parete laterale della chiesa con le finestre che la illuminavano, è stata orientata utilizzando dati estratti dalla fotografia che ritrae l'intera nicchia dal basso, fino alla base della finestra (fig. I0).

Un'ultima verifica, facilitata dalla natura tridimensionale della restituzione prospettica digitale, riguarda la posizione del fotografo all'interno della scena ricostruita; se tale posizione risultasse incongruente, se ad esempio il centro di proiezione cadesse al di sotto del pavimento o oltre i limiti dello spazio interno della chiesa, occorrerebbe riconsiderare lo schema prospettico utilizzato (fig. I I).
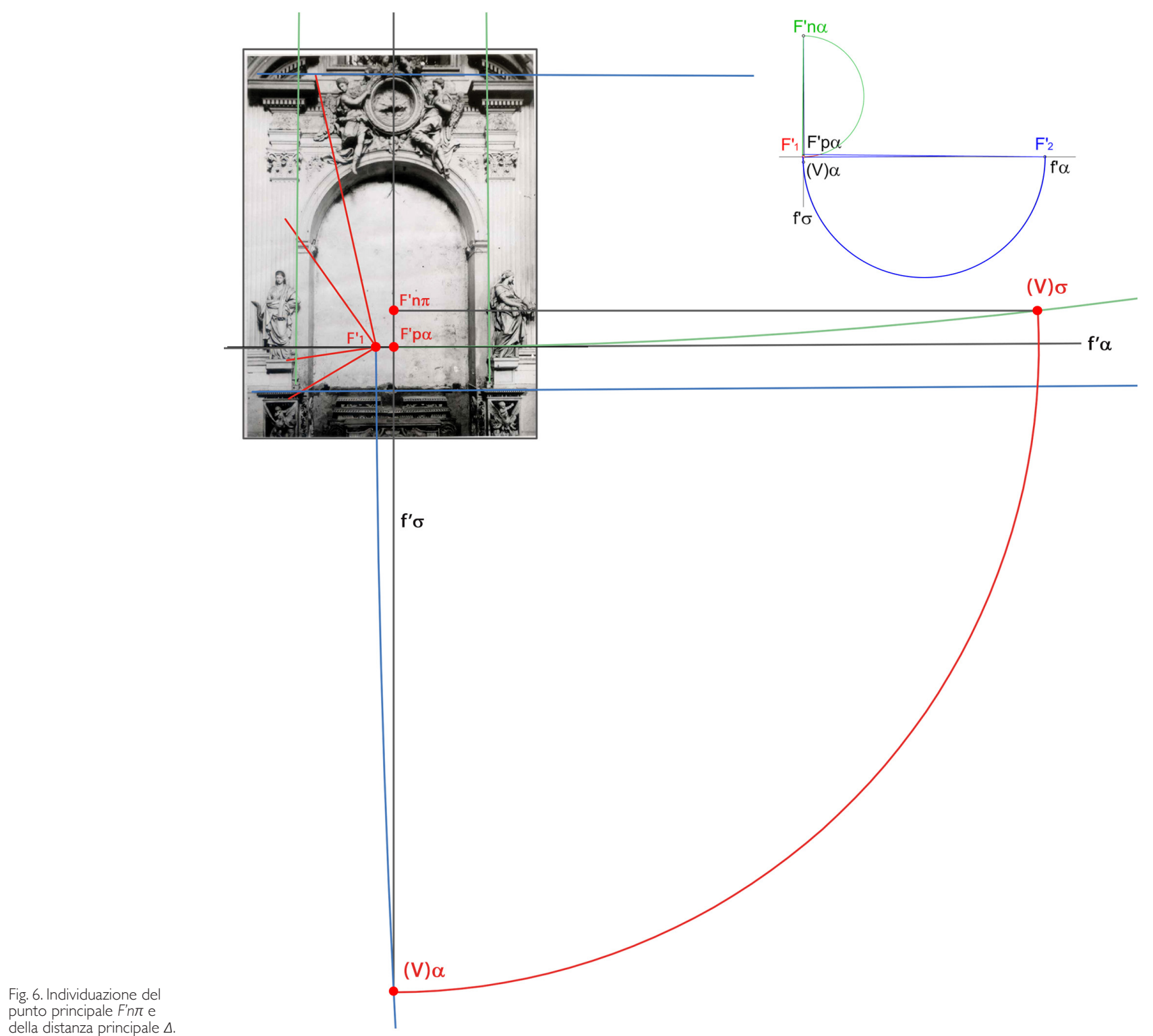
Fig. 7. Rotazioni utilizzate

per ricostruire lo schem prospettico nello spazio.

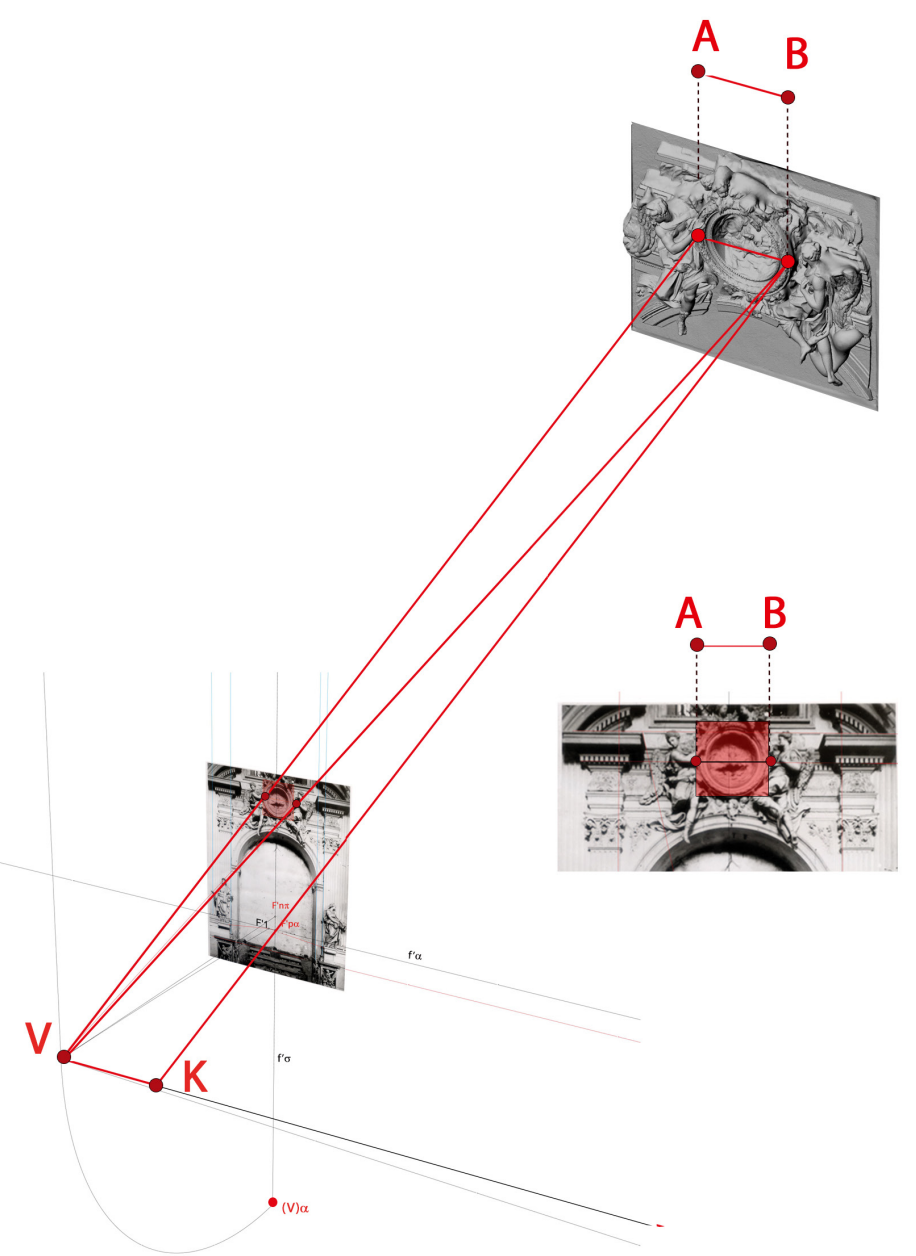

schema prospettico. 
Fig. 9. Uso di piani proiettanti per la definizione
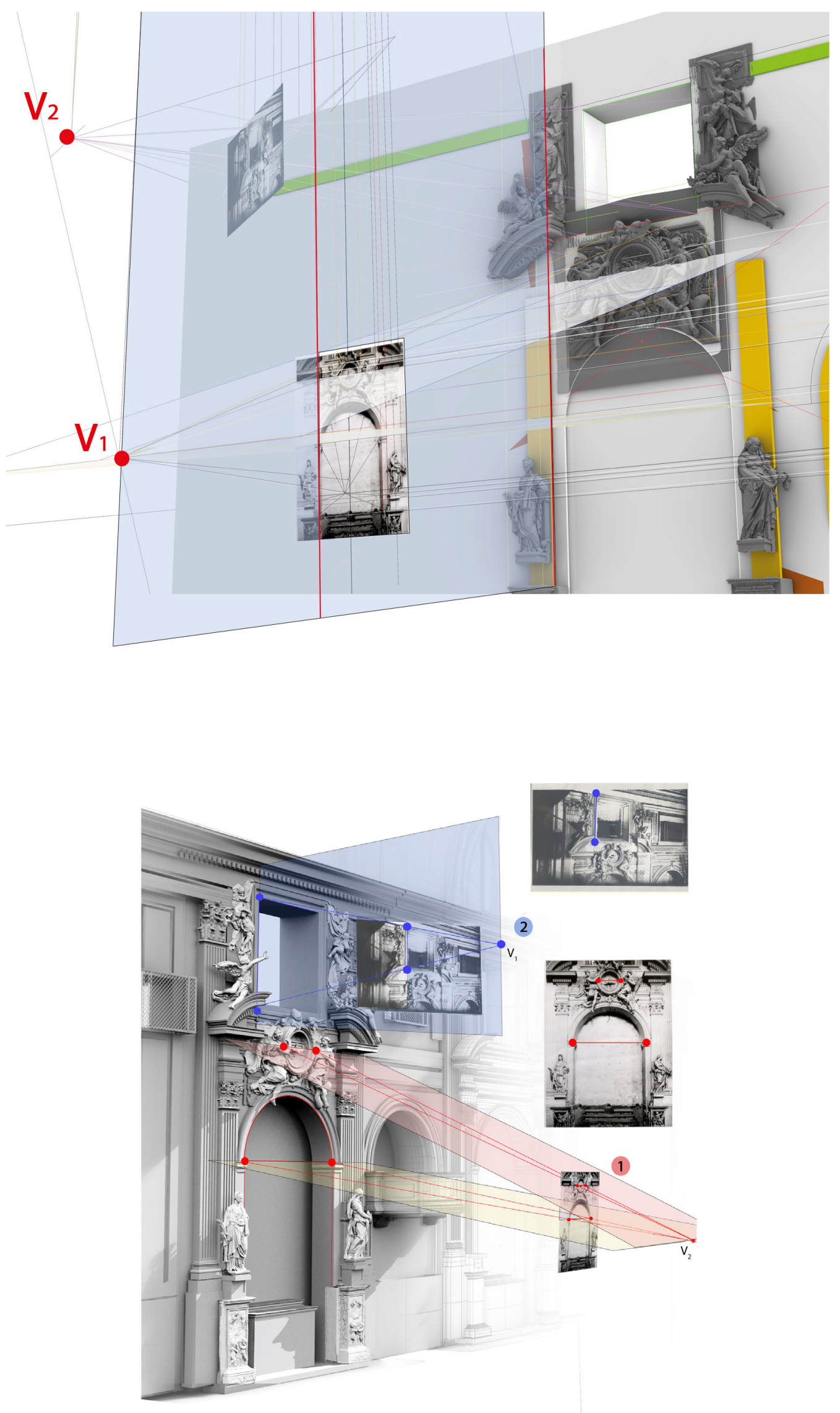


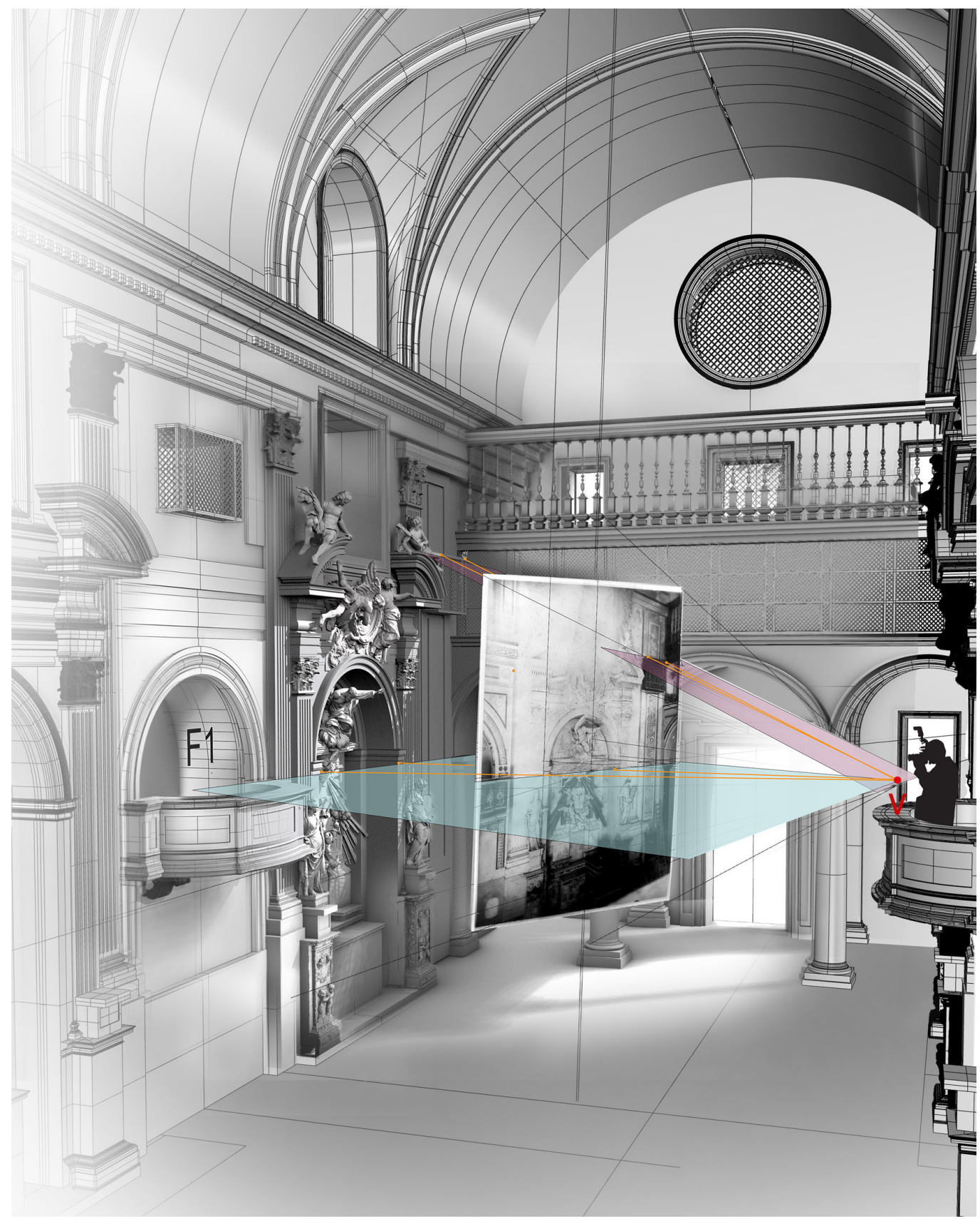

\section{Conclusioni}

Lo studio ha condotto alla ricostruzione congetturale di una chiesa demolita, attraverso la restituzione prospettica da foto d'epoca; il modello ricostruttivo è stato generato utilizzando piani proiettanti ed elementi tridimensionali di riferimento generati attraverso il rilievo di parti sopravvissute della chiesa. La restituzione prospettica rimane un processo approssimativo, ma gli strumenti digitali riducono notevolmente il margine di errore. La corrispondenza fra le fotografie e le viste corrispondenti del modello 3D (fig. 12) valida la correttezza della sperimentazione descritta e suggerisce il suo utilizzo in applicazioni di realtà virtuale, come ad esempio la produzione di immagini equirettangolari che, a partire da un'immagine d'epoca, consentano la fruizione della ricostruzione congetturale dell'intero spazio nel quale si trovava il fotografo. 


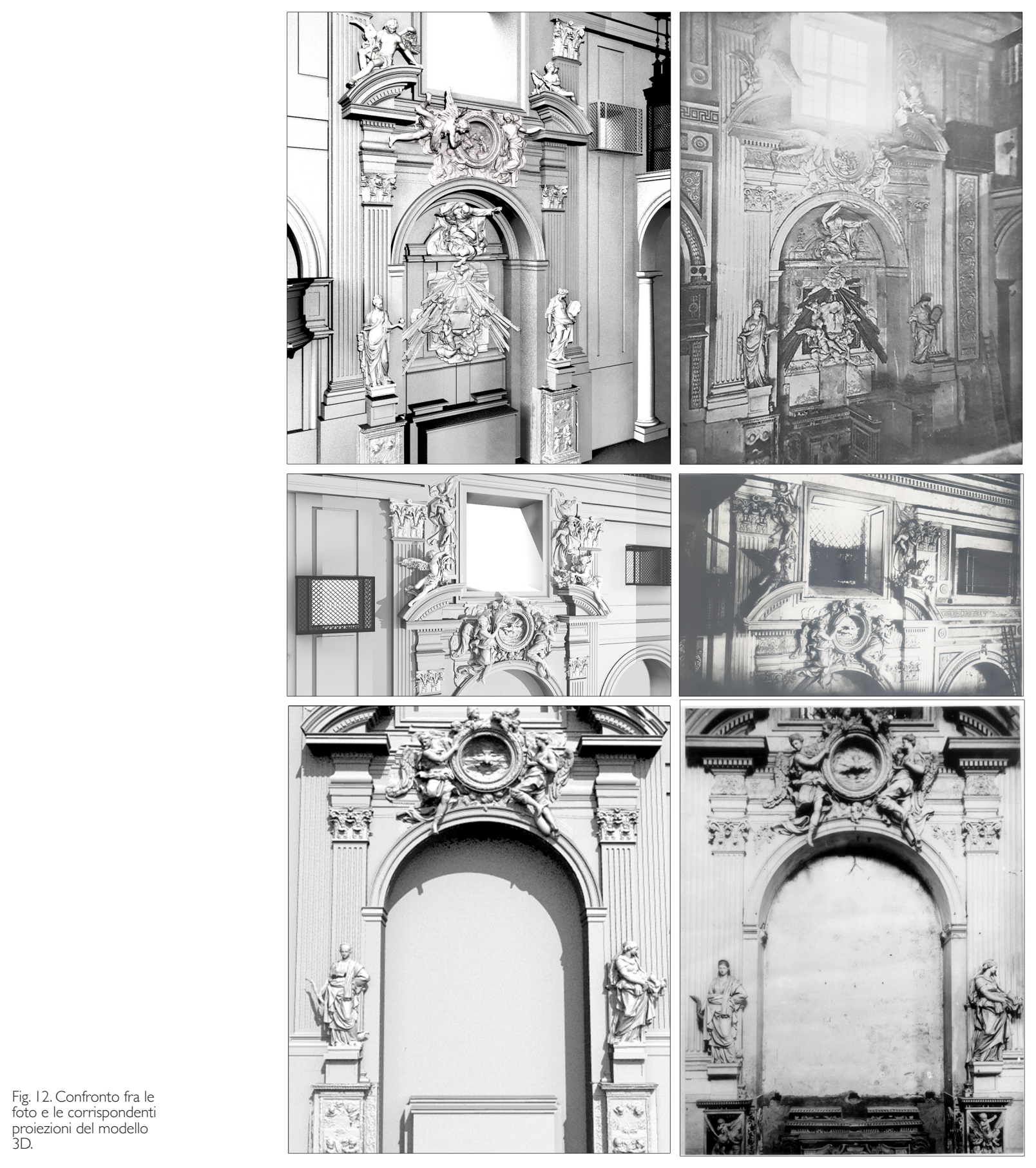




\section{Note}

[I] II dipinto di pittore siciliano ignoto, che ritrae la Processione di Santa Rosalia, appartiene alla collezione internazionale della Fundacion Casa de Alba di Madrid ed è custodito al Palacio de las Duenas a Siviglia.

[2] II processo di restituzione e modellazione è stato eseguito con il software Rhinoceros 6.0.

[3] Nelle immagini che accompagnano questo studio è stata adottata una simbologia diversa da quella comunemente adottata nei manuali di geometria descrittiva; il punto principale viene denominato F'n $\pi$, punto di fuga delle rette ortogonali (normali) al quadro $\pi$; la Linea d'orizzonte viene chiamata $f^{\prime} \alpha$, retta di fuga dei piani orizzontali; il punto di fuga delle rette verticali, ortogonali (normali) ad $\alpha$, viene chiamato F'n $\alpha$; la retta per F'n $\alpha$ e ortogonale alla f $\alpha$ è $f^{\prime} \sigma$, retta di fuga del piano sezione retta del diedro che la giacitura dei piani orizzontali forma col quadro $\pi$; il punto di intersezione fra la f $\alpha$ e la fo è $F^{\prime} p \alpha$, punto di fuga delle rette di massima pendenza dei piani orizzontali. La simbologia adottata è un omaggio alle illuminanti lezioni di Geometria descrittiva del prof. Michele Inzerillo.

[4] I piani sezioni retta contengono le direzioni delle rette ortogonali a entrambi i piani che compongono il diedro.

[5] Se l'angolo è retto, è sufficiente tracciare la semicirconferenza che ha come diametro il segmento della f $\alpha$ delimitato dai due punti di fuga; se invece l'angolo è acuto o ottuso, occorre utilizzare procedure che applicano le relazioni tra angoli al centro e angoli alla circonferenza; per limiti editoriali, tale evenienza non viene discussa in questa sede.

[6] La direzione di una retta ortogonale ad $\alpha$ forma angoli retti con tutte le direzioni del piano $\alpha$ e pertanto anche con la direzione della retta di massima pendenza.

\section{Riferimenti bibliografici}

Aguilera Diego Gonzales, Claro-Irisarri Manuel Alvarez, Gomez Lahoz Javier, Finat Javier, Gonzalo-Tasis Margarita (2004). Development of a simulator for reliable and accurate 3D Reconstruction from a single view. In International Archives of the Photogrammetry, Remote Sensing \& Spatial Information Sciences, Vol. 35, 2004, pp. I 42 - I 47.

Arslan Ozan (2014). 3D Object Reconstruction from a Single Image. In International Journal of Environment and Geoinformatics, I, 2014 , pp. $21-28$

Docci Mario, Maestri Diego (1994). Manuale di rilevamento architettonico e urbano. Bari: Laterza.

Fallavollita Federico, Migliari Riccardo, Salvatore Marta (2013). Monge e il problema del vertice di piramide: una applicazione alla restituzione di quote e volumi da una fotografia del I892. In DisegnareCon, Vol. 6, n. I2, 20 I 3, pp. IX/I-9.

Fano Gaetano (1979). La restituzione prospettica da prospettiva razionale. Bari: Dedalo.

Meli Filippo (1934). Serpotta, la vita e le opere. Palermo: Società siciliana per la Storia Patria.

\section{Autori}

Fabrizio Agnello, Università di Palermo, fabrizio.agnello@unipa.it

Laura Barrale, Università di Palermo, Ibarrale@libero.it

Per citare questo capitolo: Fabrizio Agnello, Laura Barrale (2020). Riannodare il passato e il presente con la restituzione prospettica: ricostruzione della perduta chiesa delle Stimmate di Palermo da foto d'archivio/Weaving past and present with the help of perspective restitution: reconstruction of the gone stimmate church of Palermo from period photos. In Arena A., Arena M., Brandolino R.G., Colistra D., Ginex G., Mediati D., Nucifora S., Raffa P. (2020). Connettere. Un disegno per annodare e tessere. Atti del $42^{\circ}$ Convegno Internazionale dei Docenti delle Discipline della Rappresentazione/Connecting. Drawing for weaving relationships. Proceedings of the 42 th International Conference of Representation Disciplines Teachers. Milano: FrancoAngeli, pp. | 486-I509. 


\title{
Weaving Past and Present with the Help of Perspective Restitution: Reconstruction of the Gone Stimmate Church of Palermo from Period Photos
}

\author{
Fabrizio Agnello \\ Laura Barrale
}

Abstract

Perspective restitution belongs to the disciplinary corpus of descriptive geometry, as an inverse problem of perspective. In the past, this technique has rarely been used for the reconstruction from photos of lost monuments and works of art; digital modeling tools suggest reconsidering perspective restitution as an effective tool for the reconstruction of lost monuments portrayed in period photos. The case study is the Stimmate church of Palermo, demolished at the end of the 19th century for the construction of a theatre. The nave of the church was delimited by walls with shallow arched niches, decorated with precious stuccos that were saved from demolition and are now exhibited at the Oratorio dei Bianchi in Palermo.

No drawing documents the demolished church; the only surviving documentation are three low quality photos, which portray two opposing niches of the church, decorated with stuccos. Perspective restitution technique led to retrieve the inner orientation of the images, i.e. the position of the point of view and its distance from the image, proportionally referred to the width of the image in the modeling software. 3D survey provided the models of the stuccos exhibited at the Oratorio dei Bianchi that were used to scale and orient the perspective model and, finally, to virtually reposition the survived sculptural elements in the reconstructive model of the niches.

Keywords

perspective restitution, 3D virtual reconstruction, Serpotta, Stimmate Church, Massimo Theatre.

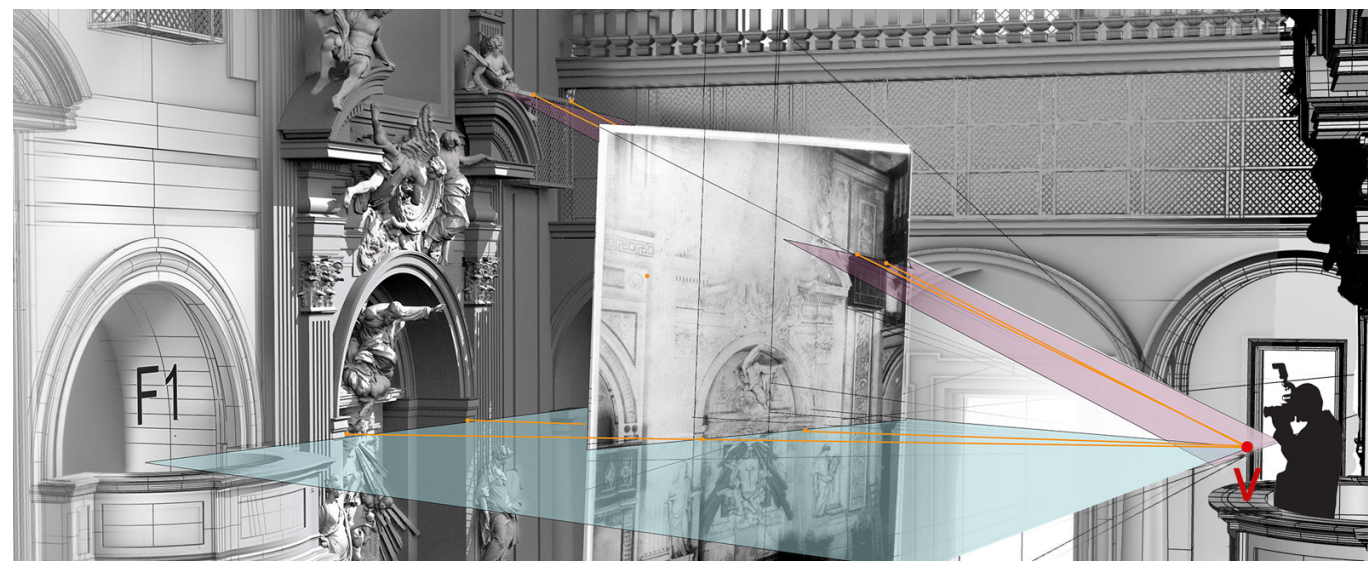




\section{Introduction}

Digital perspective restitution is a powerful tool that can support the 3D reconstruction of buildings that were destroyed and are documented by few old photos. The Stimmate church was built at the beginning of the 17th century near the northern edge of the historic center of Palermo; the church and the annexed female monastery were demolished in 1890, as a part of a vast urban transformation program aimed at clearing a wide area close to the sixteenth-century walls, where Palermo's main opera house, the Massimo theatre, was to be built. Like most of the churches annexed to female monasteries, the Stimmate church had a single nave, delimited by walls with shallow niches and ended by a rectangular apse; two facing niches, located near the entrance, were decorated with stucco statues, sculpted by Giacomo Serpotta, one of the most important Sicilian artists of the period.

The stuccos were removed before the demolition of the church and exhibited in the former National Museum of Palermo (today Salinas Archaeological Museum); at the end of the millennium they were restored and set on the ground floor of the Oratorio dei Bianchi, a monument annexed to the Regional Gallery of Palazzo Abatellis (fig. I).

No drawing of the church has come to us; a painting of an unknown author dated early I 8th century depicts the monuments of Palermo located along the path of the religious procession of Santa Rosalia [I]; the writing Badia Delli Stimmati overlays the facade of a church. The painted facade has little relevance since its shape fits the standard layout of the facade of a three-nave church.

Another document, much more reliable, is the Piano di Massima della ubicazione del nuovo Teatro, drawn up by Giovan Battista Filippo Basile, architect in charge of the project and

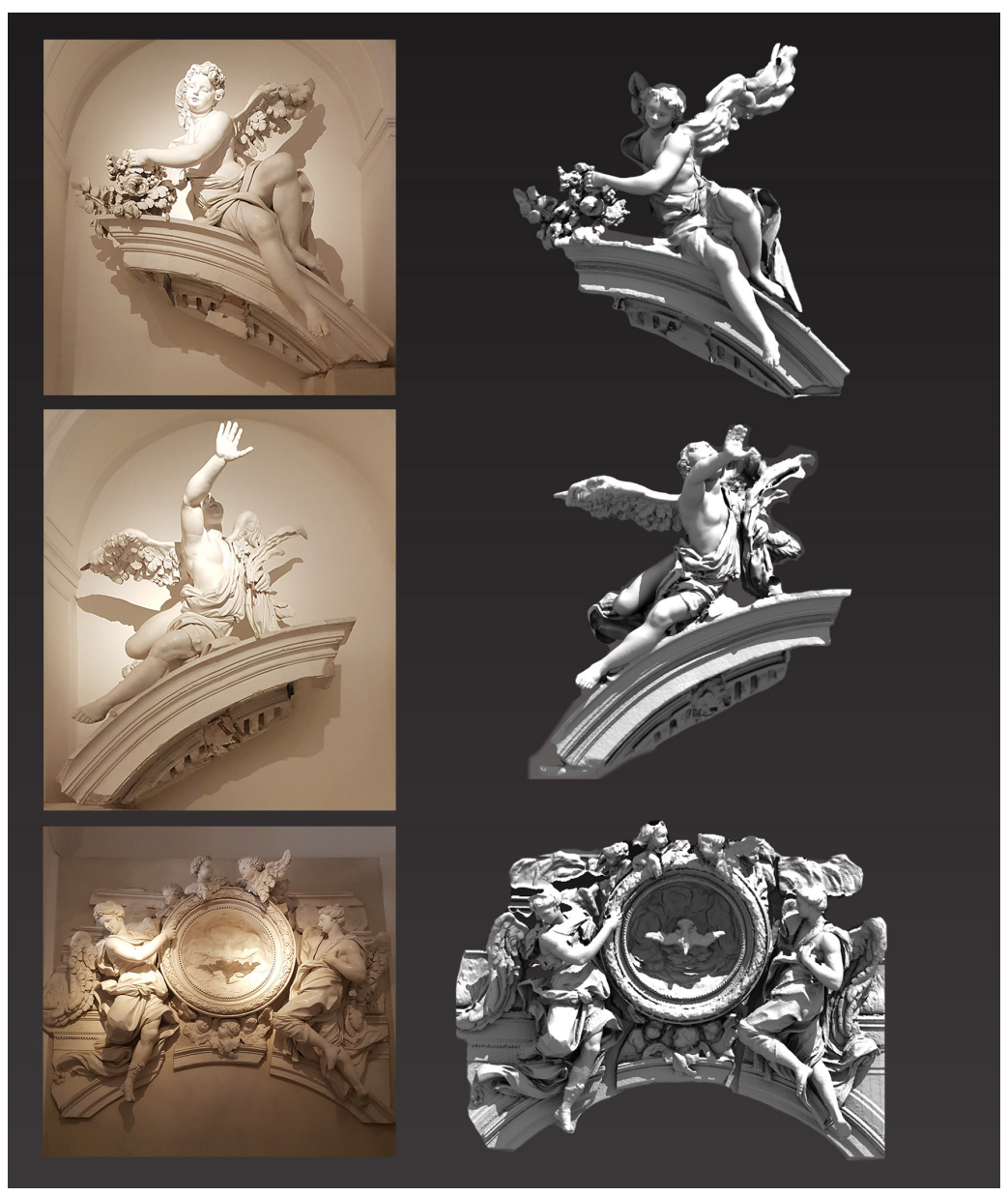


Fig. 2. Period photos documenting the interior of the church. construction of the Massimo theatre. Basile's Piano is an accurate plan of the area where the theatre was to be built; the outline of the theatre overlays the outline of the extant buildings. The comparison with the 198I map of the historic center of Palermo and with the laser scanner survey of the area confirmed the metric accuracy of the Piano. The perimeter of the Stimmate church, clearly marked in the Piano, provided the overall size of the church.

The only sources documenting the layout of the interior spaces of the church are three photos, taken at the end of July 1890, soon before the demolition; the photos, which exclusively display the stucco niches (fig. 2), were probably taken to document their original position in view of a later exhibition in the National museum. The three low quality images have come to us in books that do not mention the source. The stuccos, sculpted by Giacomo Serpotta, one of the most famous artists in Palermo in the 17th century, were the most valuable works of art of the Stimmate church.
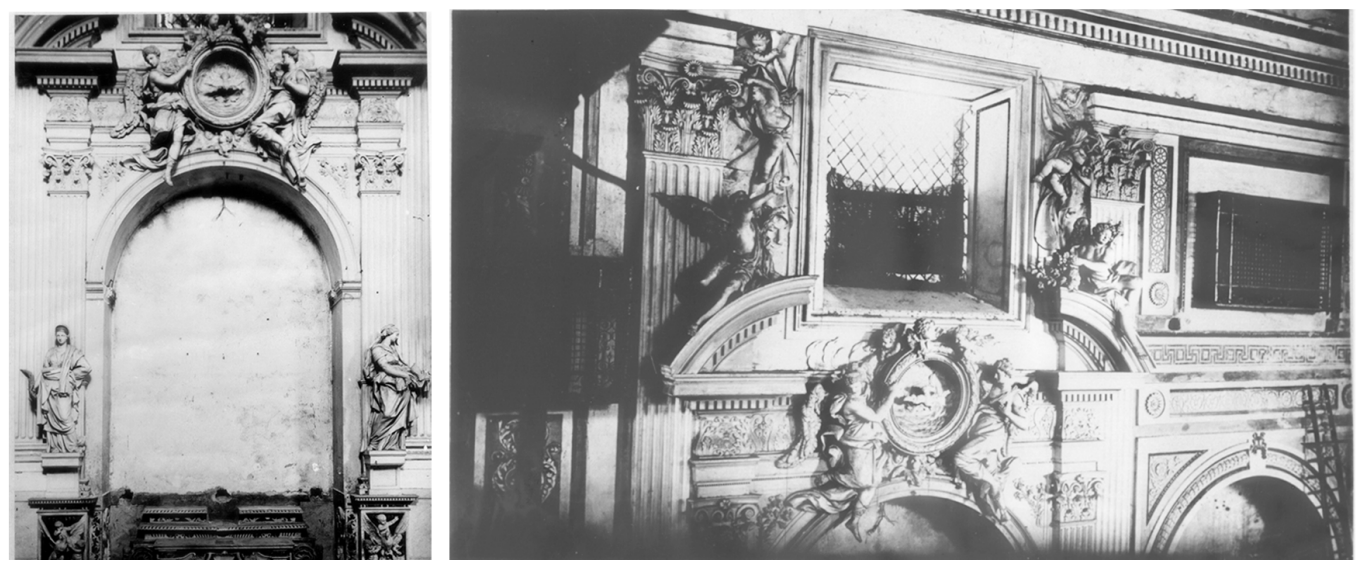

\section{State of art}

Perspective restitution belongs to the disciplinary corpus of descriptive geometry, as an inverse problem of perspective. In the past, this technique has rarely been used for the reconstruction from period photos of gone monuments and works of art, probably due to the inaccuracy of traditional drawing tools, inadequate to ensure the restitution from photos an acceptable accuracy. The small size of printed photos, inaccessible vanishing points, the restitution limited to the rotation of flat figures on the picture plane, have made perspective restitution a marginal player in the researches aiming at the reconstruction of the past.

Digital drawing and modeling tools offer today the opportunity to enhance this old technique, increasing its accuracy and effectiveness. Few publications (see bibliography) give evidence of an initial but solid interest of scholars in representation science towards the use of digital perspective restitution for the 3D reconstruction from photos.

Digital technology has significantly improved the workflow and the outputs of perspective restitution; the unlimited size of the drawing surface makes it possible to detect even the farthest vanishing points; restitution can be operated directly in space; the possibility of setting cameras that match the projection center and the focal length allows checking in real time the correspondence between the size and position of an element and its photographic image. 
The perspective restitution process can therefore usefully be applied to the construction of three-dimensional models.

All photogrammetric techniques, and perspective restitution as well, are not self-sufficient surveying methods because they can restitute nothing more than proportions; in order to make geometric proportioned entities measurable, the photogrammetric model must be scaled according to the size of elements displayed in one or more photos.

The photogrammetric survey, and the perspective restitution, becomes metric only thanks to measurements taken with direct, topographic or laser scanning methods.

When an element displayed in the photo is surveyed with laser scanning techniques, a cloud of points (or a mesh) documents its three-dimensional features. The photogrammetric model can be scaled with the use of one dimensions of the 3D element and the accuracy of the accuracy of the perspective restitution scheme can be visually checked through the correspondence, from the projection center, between the 3D element and its photographic image.

\section{Photo's orientation}

The first step of the restitution process obviously consists in uploading the digitized image in a modeling software [2].The dimension of the image is not relevant since the entire perspective scheme can be scaled at any time.

In ideal conditions (a digital photo, for example) the principal point, i.e. the vanishing point of the lines at right angle with the picture plane, matches the intersection of the diagonals of the rectangular image frame.

When working on images that come from books or other sources, it may happen that the principal point is in a different position; this usually happens when:

- the original image was cut out for editorial needs;

- the image was taken with a view camera, a device used to reduce the convergence of vertical lines (fig. 3).

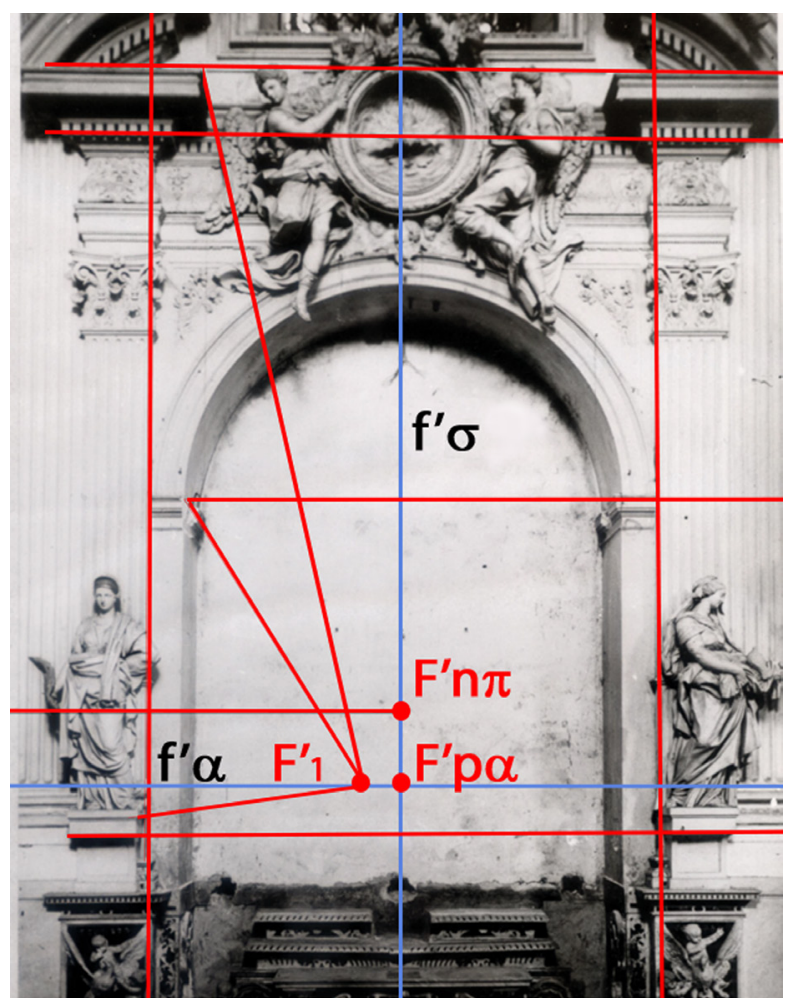


In the first case, knowledge of the proportions of the negative or of the glass plate, or a research on the dating of the image and on the most popular formats of the period, can be useful.

For the decentralization due to the use of the optical bench, please refer to what is explained a little further on.

The second step was dedicated to the detection of $F^{\prime} n \alpha$, the vanishing point of the vertical lines [3]; working with photographic images it is almost impossible to find parallel vertical lines parallel; this would happen if the picture plane were vertical, that is if the photographer had taken the shot while holding the camera so that the axis of the lens was exactly horizontal. The perspective restitution from photos was often impossible to achieve due to the faraway position of $F^{\prime} n \alpha$, due to the limited inclination of the camera when shooting was performed (fig. 4).

The third step aims at detecting the horizon line, $f \alpha$, with the use of two vanishing points of horizontal lines; $f \alpha$ is never parallel to the horizontal edges of the photographic image; this would happen if the photographer had kept the base of the camera perfectly horizontal while shooting.

The perspective scheme is rotated to assign $f \alpha$ a horizontal direction and $f \sigma$, the vanishing line of the plane at right angle with the dihedron made by $\alpha$ and $\pi$, is drawn; f $\sigma$ starts from $F^{\prime} n \alpha$ [4] and cuts the $f \alpha$ at right angle in in $F^{\prime} p \alpha$, the vanishing point of the straight lines made by the intersection of $\alpha$ and $\sigma$ (fig. 5).

The angle formed by the horizontal lines used to detect the vanishing points, allows the drawing of a circumference through these points [5]. The intersection between the circumference and the vertical line through $F^{\prime} n \alpha$ is $(V) \underline{\alpha}$, rotation of the projection point $V$ on the picture plane, with the use of the horizontal projecting plane (rotation axis $f \alpha$ ).

The segment from $F^{\prime} p \alpha$ to $(V) \underline{\alpha}$ is the rotation on $\pi$ of the segment from $F^{\prime} p \alpha$ to $V$, belonging to the intersection line between $\alpha$ and $\sigma$; this segment is the radius of circle arc centered on $F^{\prime} p \alpha$, that intersects in $(V) \underline{\sigma}$ the semicircle whose diameter spans from $F^{\prime} p \alpha$ to $F^{\prime} n \alpha$ [6].

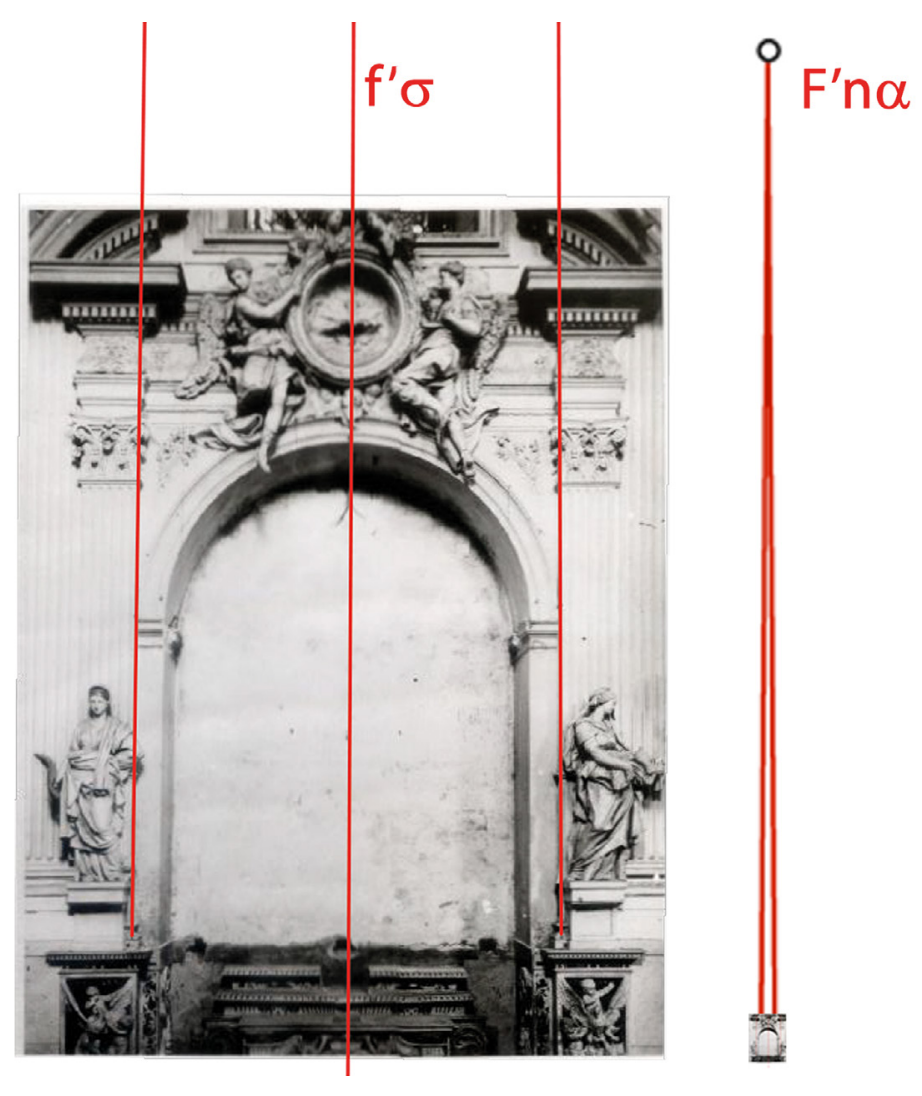


$(V) \underline{\sigma}$ is the rotation on the picture plane of of the projection point $V$ (rotation axis $f \sigma$ ); the line through $(V) \underline{\sigma}$ that intersects $f \sigma$ at right angle, detects the principal point $F$ 'n $\pi$ and the principal distance (focus length) $\Delta$ (fig. 6).

The following rotations allowed to set the 3D layout of the perspective scheme:

- a rotation at right angle around the $f \sigma$ has restituted the $3 D$ position of $V$;

- a rotation on plane $\sigma$ assigns vertical direction to the line through $V$ and F'n $\alpha$ and, consequently, horizontal position to plane $\alpha$ (fig. 7);

- a rotation on plane $\alpha$ plane assigns a horizontal direction of the perspective scheme the corresponding direction of a line belonging to the $3 \mathrm{D}$ element that was used for scaling purposes.

The parallelogram rule has been applied (fig. 8):

- using the segment $A^{\prime} B^{\prime}$ of the line $r$ which vanishes in $F^{\prime}$;

- identifying the corresponding segment $A B$ on the line $r$ of the $3 D$ element;

- drawing the lines from $V$ to $A^{\prime}$ and $B^{\prime}$;

- reporting on the segment from $V$ to $F^{\prime}$, a segment $V K$, whose length equals $A B$;

- drawing, from point $K$, a line parallel to the line from $V$ to $A^{\prime}$; this line intersects the line from $V$ to $B^{\prime}$ in the point $B$;

- moving the 3D element so that its point $B$ matches the reconstructed point $B$.

The quality of the reconstruction of the perspective scheme is checked by setting a camera on the projection center and assigning it a focal length that equals the principal distance $\Delta$; the correspondence between the 3D element and its photographic image is checked by making the photo transparent.

The perspective scheme is therefore set up and restitution can be started. After placing a vertical plane to the back wall of the stucco 3D element, the straight lines that encompass the shape of the niches were determined with the help of planes identified by three points: the projection center $V$, the vanishing point of the line that is under restitution, a point of the line on the photo; the intersection between the plane and the photo must exactly overlap the image of the line (fig. 9).

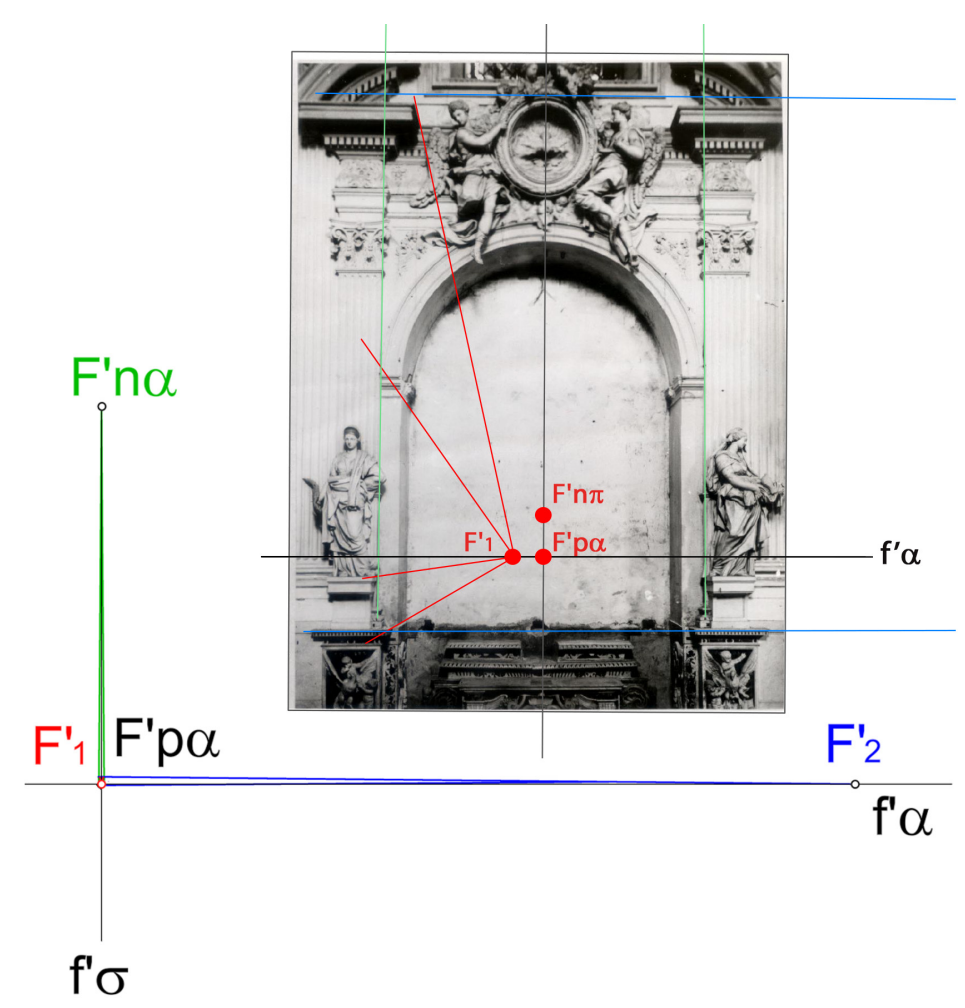


The prospective return can be carried out with a chain sequence, using dimensions and directions coming from previous restitutions to scale and orient further photos; in this study, the photograph of the upper part of the niche, which includes the upper part of the walls of the church, opened by windows, was oriented using data extracted from the restitution of the photo that portrays the entire niche, from the floor to the lower edge of the windows (fig. I0).

A final check, allowed by the three-dimensional layout of digital perspective restitution, concerns the photographer's position within the reconstructed scene; if this position is inconsistent, i.e. the projection center falls below the floor or beyond the limits of the internal space of the church, it would be necessary to reconsider the perspective scheme (fig. II).

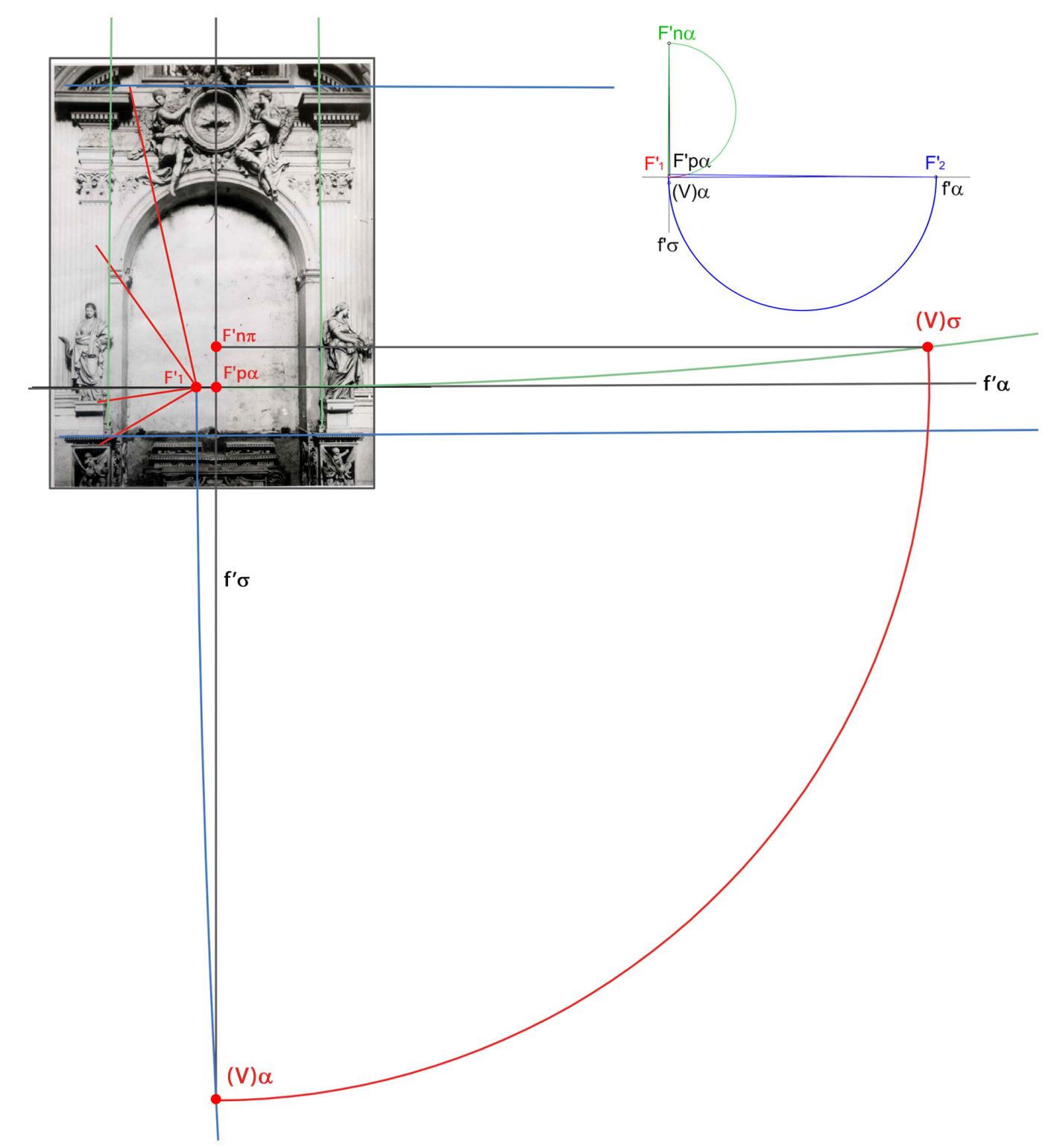


Fig. 7. Rotations used to

set up the 3D layout of

the perspective scheme.
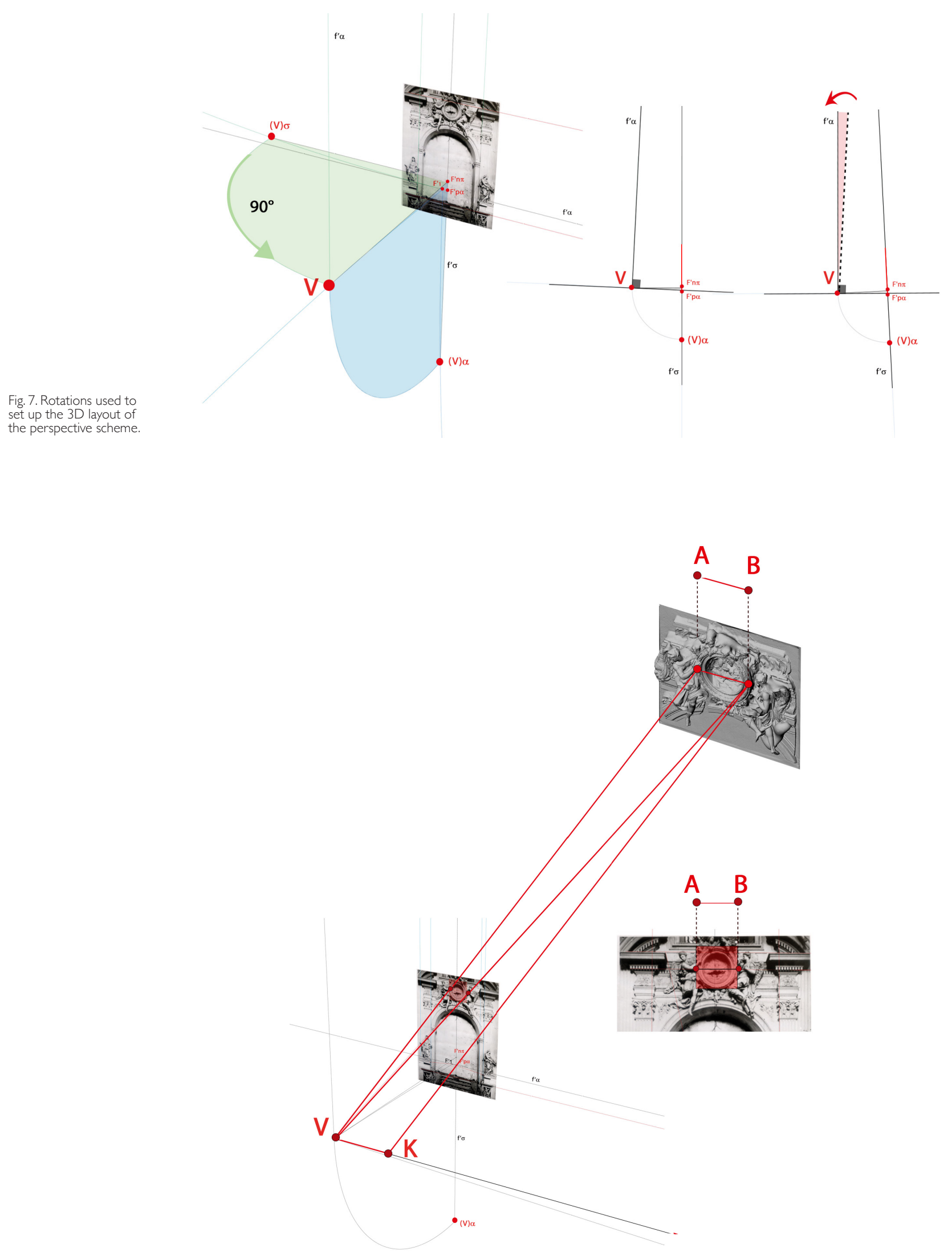
Fig. 9. Planes through the projection point used to build up the $3 \mathrm{D}$ reconstruction model.
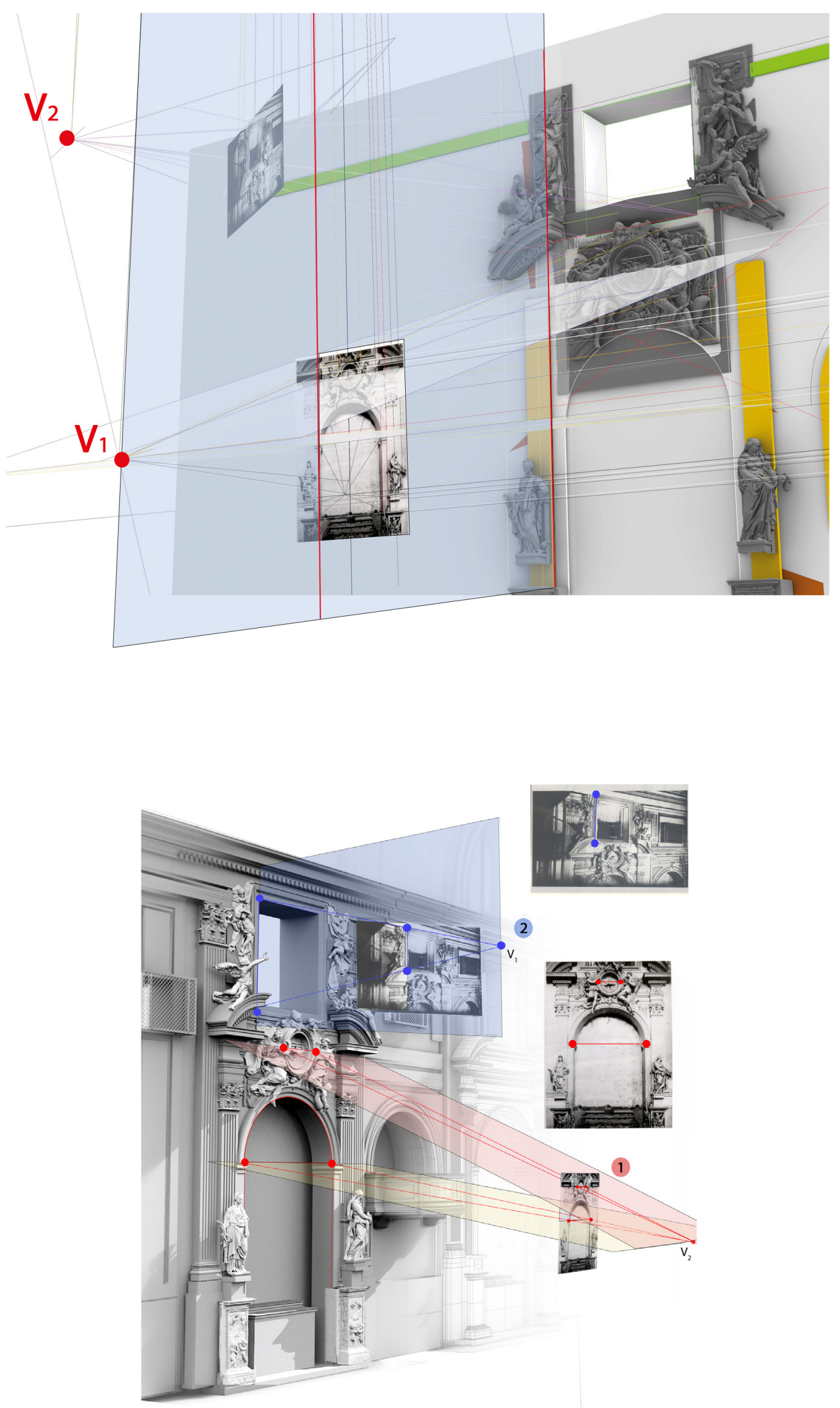
Fig. I I.Validation of the photographer's position inside the church.

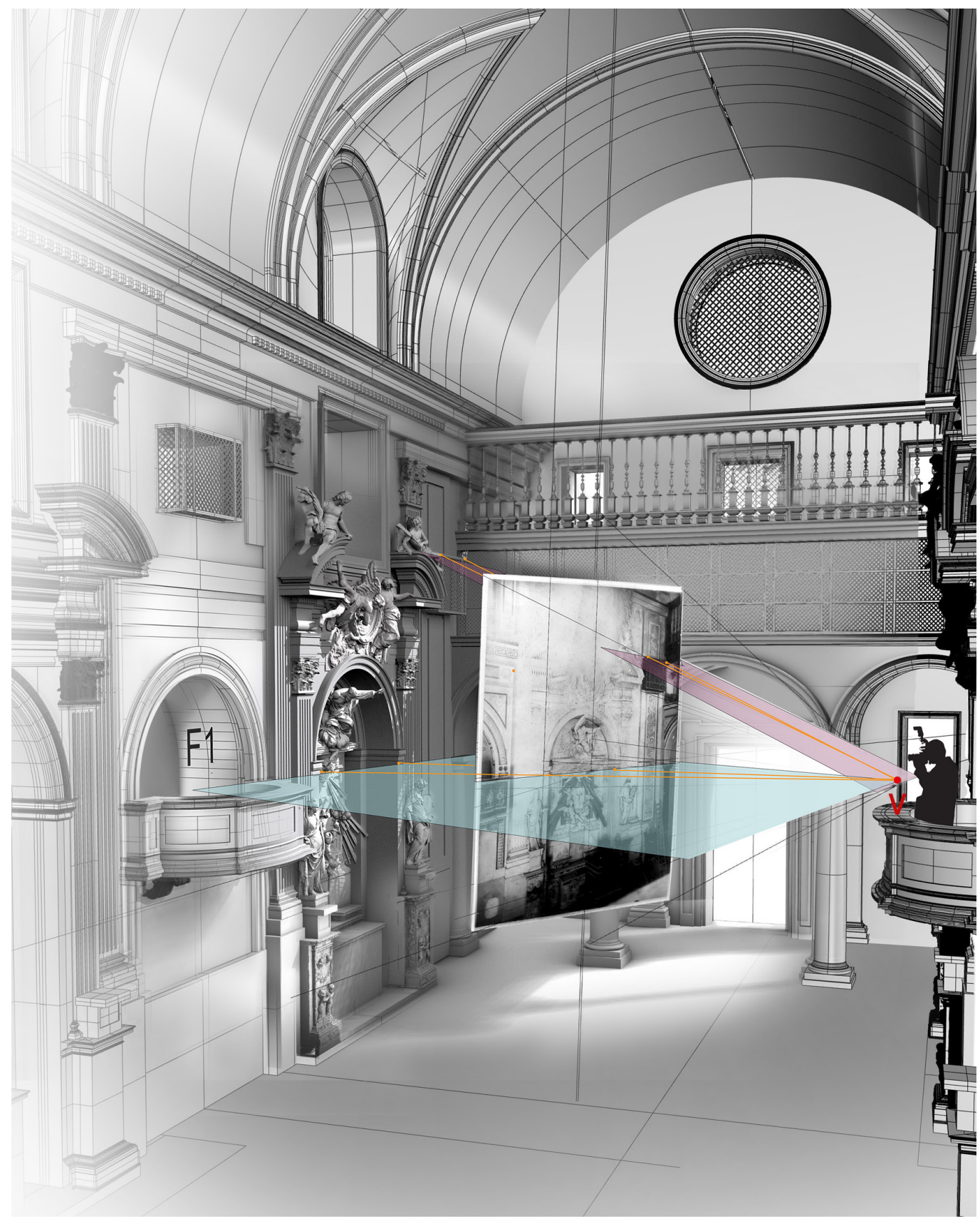

\section{Conclusions}

The discussed study led to the reconstruction of a demolished church, through the perspective restitution of period photos; the reconstructive model was generated using projecting planes and three-dimensional reference elements built by the survey of surviving parts of the church. Prospective restitution remains an approximate process, but digital tools significantly reduces the error. The correspondence between the photographs and the corresponding views of the 3D model (fig. 12 ) validates the accuracy of the proposed method and suggests its use in virtual reality applications, such as the production of equirectangular images that, starting from a period image, allow the visualization of the reconstruction of the entire space surrounding the photographer at the time of the shooting. 
Fig. 12. Comparison between photos and the corresponding views of

the $3 \mathrm{D}$ reconstructed model.
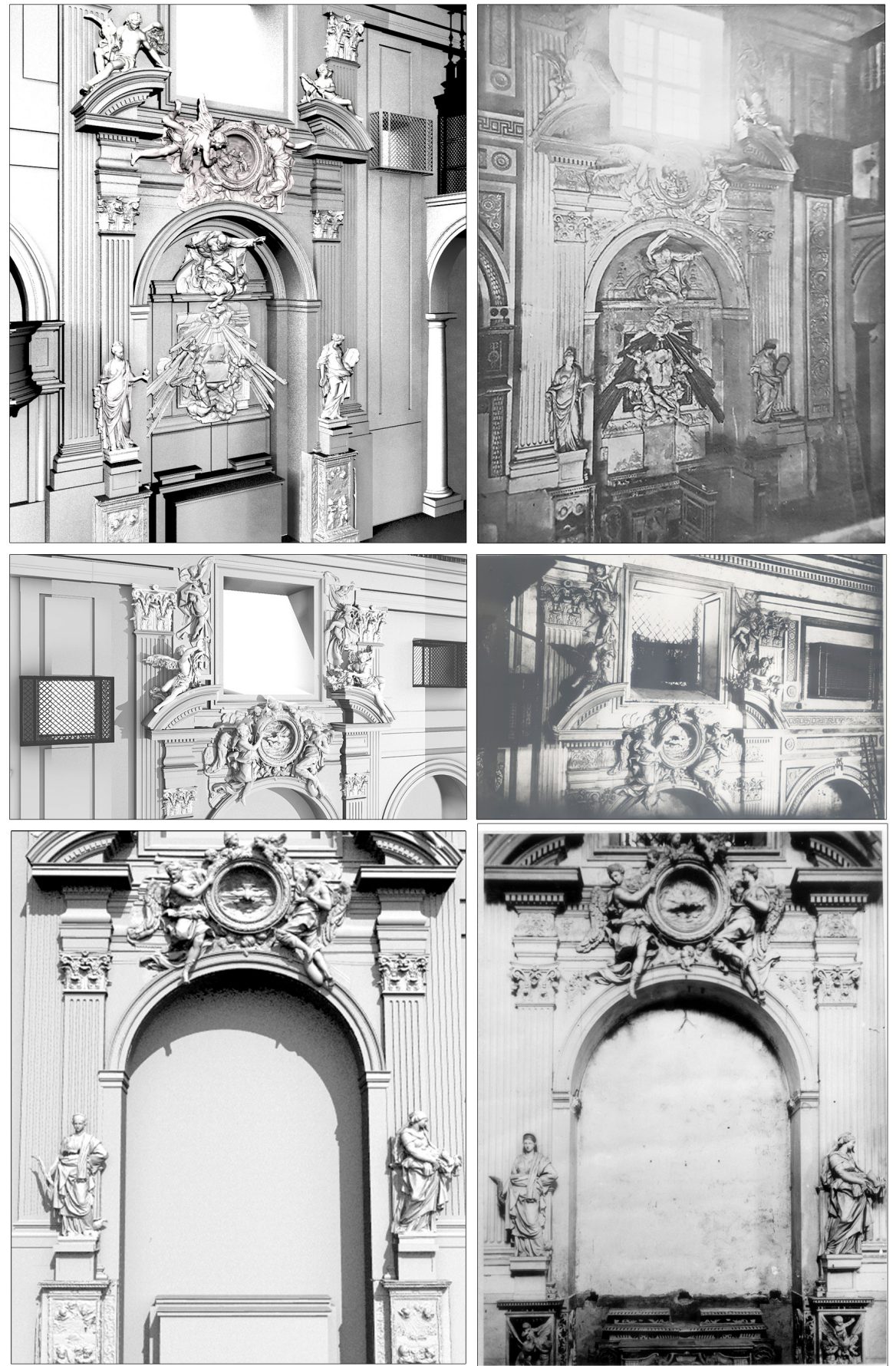


\section{Notes}

[I] The painting by an unknown Sicilian painter, which portrays the Procession of Santa Rosalia, belongs to the international collection of the Fundacion Casa de Alba in Madrid and is kept in the Palacio de las Duenas in Seville.

[2] The restitution and modeling process was performed with Rhinoceros 6.0.

[3] In the images illustrating this study, the symbols used are almost different from those commonly adopted in the descriptive geometry manuals; the principal point, that is the vanishing point of the lines at right angle (normal) to the picture plane $\varpi$, is called $F^{\prime} n \pi$; the horizon line, that is the vanishing line of the horizontal planes, is called $f \alpha$; the vanishing point of the vertical lines, at right angle (normal) to $\alpha$, is called F'n $\alpha$; the line through F'n $\alpha$ at right angle to $f^{\prime} \alpha$ is $f^{\prime} \sigma$, vanishing line of the plane that cuts at right angle the dihedron made by the intersection of the picture plane $\pi$ and the horizontal plane $\alpha$; the intersection point between $f^{\prime} \alpha$ and $f^{\prime} \sigma$ is $F^{\prime} p \alpha$, the vanishing point of the lines resulting from the intersection of $\sigma$ and $\alpha$. The adopted symbolism is a tribute to the illuminating lessons on perspective of prof. Michele Inzerillo (1940-2015).

[4] The plane at right angle with the two combining a dihedron, matches the directions of the lines at right angle with both of them.

[5] If the angle is right, a semicircle whose diameter matches the distance between the two vanishing points is drawn; if the angle is acute or obtuse, it is necessary to apply the relationships between angles in the center and angles at the circumference; for editorial limitations, this event is not discussed here.

[6] The direction of a line at right angle to $\alpha$ forms right angles with all the directions of plane $\alpha$ and therefore with the line resulting from the intersection of $\alpha$ and $\sigma$.

\section{References}

Aguilera Diego Gonzales, Claro-Irisarri Manuel Alvarez, Gomez Lahoz Javier, Finat Javier, Gonzalo-Tasis Margarita (2004). Development of a simulator for reliable and accurate 3D Reconstruction from a single view. In International Archives of the Photogrammetry, Remote Sensing \& Spatial Information Sciences, Vol. 35, 2004, pp. I 42- 47.

Arslan Ozan (20I4). 3D Object Reconstruction from a Single Image. In International Journal of Environment and Geoinformatics, ।, 2014 , pp. $21-28$

Docci Mario, Maestri Diego (1994). Manuale di rilevamento architettonico e urbano. Bari: Laterza.

Fallavollita Federico, Migliari Riccardo, Salvatore Marta (2013). Monge e il problema del vertice di piramide: una applicazione alla restituzione di quote e volumi da una fotografia del I892. In DisegnareCon, Vol. 6, n. 12, 20 I 3, pp. IX/I-9.

Fano Gaetano (1979). La restituzione prospettica da prospettiva razionale. Bari: Dedalo.

Meli Filippo (1934). Serpotta, la vita e le opere. Palermo: Società siciliana per la Storia Patria.

\section{Authors}

Fabrizio Agnello, Università di Palermo, fabrizio.agnello@unipa.it

Laura Barrale, Università di Palermo, lbarrale@libero.it

To cite this chapter. Fabrizio Agnello, Laura Barrale (2020). Riannodare il passato e il presente con la restituzione prospettica: ricostruzione della perduta chiesa delle Stimmate di Palermo da foto d'archivio/Weaving past and present with the help of perspective restitution: reconstruction of the gone stimmate church of Palermo from period photos. In Arena A., Arena M., Brandolino R.G., Colistra D., Ginex G., Mediati D., Nucifora S., Raffa P. (2020). Connettere. Un disegno per annodare e tessere. Atti del $42^{\circ}$ Convegno Internazionale dei Docenti delle Discipline della Rappresentazione/Connecting. Drawing for weaving relationships. Proceedings of the 42 th International Conference of Representation Disciplines Teachers. Milano: FrancoAngeli, pp. | 486-1509. 